\title{
Added Value of Blood Cells in Thrombin Generation Testing
}

\author{
Jun Wan ${ }^{1,2}$ Joke Konings ${ }^{1,2}$ Bas de Laat ${ }^{1,2}$ Tilman M. Hackeng ${ }^{2}$ Mark Roest ${ }^{1,2}$ \\ 1 Synapse Research Institute, Maastricht, The Netherlands \\ 2 Department of Biochemistry, Cardiovascular Research Institute \\ Address for correspondence Jun Wan, MSc, Pastoor Habetsstraat 50, \\ Maastricht, Maastricht University, Maastricht, The Netherlands \\ 6217 KM, Maastricht, The Netherlands \\ (e-mail: j.wan@maastrichtuniversity.nl).
}

Thromb Haemost 2021;121:1574-1587.

Abstract


Keywords
- thrombosis
- haemorrhage
- thrombin generation
- blood cells
- whole blood

The capacity of blood to form thrombin is a critical determinant of coagulability. Plasma thrombin generation (TG), a test that probes the capacity of plasma to form thrombin, has improved our knowledge of the coagulation system and shows promising utility in coagulation management. Although plasma TG gives comprehensive insights into the function of pro- and anticoagulation drivers, it does not measure the role of blood cells in TG. In this literature review, we discuss currently available continuous TG tests that can reflect the involvement of blood cells in coagulation, in particular the fluorogenic assays that allow continuous measurement in platelet-rich plasma and whole blood. We also provide an overview about the influence of blood cells on blood coagulation, with emphasis on the direct influence of blood cells on TG. Platelets accelerate the initiation and velocity of TG by phosphatidylserine exposure, granule content release and surface receptor interaction with coagulation proteins. Erythrocytes are also major providers of phosphatidylserine, and erythrocyte membranes trigger contact activation. Furthermore, leukocytes and cancer cells may be important players in cell-mediated coagulation because, under certain conditions, they express tissue factor, release procoagulant components and can induce platelet activation. We argue that testing TG in the presence of blood cells may be useful to distinguish blood cell-related coagulation disorders. However, it should also be noted that these blood cell-dependent TG assays are not clinically validated. Further standardization and validation studies are needed to explore their clinical usefulness.

\section{Introduction}

The blood coagulation system consists of a serial of coagulation factors and cofactors that are separated from their physiological activators by the endothelium under normal conditions. ${ }^{1-4}$ Upon exposure to subendothelial tissue factor $(\mathrm{TF})^{5}$ or intravascular $\mathrm{TF}^{6-10}$ coagulation could be triggered by the formation of the factor(F) VII-TF complex, which then triggers the formation of a tiny amount of thrombin through the activation of FIX and FX on a negatively charged surface. ${ }^{11-14}$ Thrombin amplifies its own formation via positive

received

November 30, 2020

accepted

March 18, 2021

published online

March 19, 2021 feedback loops involving the activation of FXI, FVIII and FV. ${ }^{15,16}$ The subsequent burst of thrombin converts fibrinogen into fibrin monomers, which polymerize and are crosslinked into a dense clot to seal the wound. Meanwhile, thrombin also limits its own production through negative feedback by acting together with the endothelial receptor thrombomodulin to activate the anticoagulant protein $\mathrm{C}$. Activated protein $C$ (APC), together with cofactor protein $S$, cleaves FVIIIa and FVa to regulate the amount of thrombin generated. ${ }^{13,14,17,18}$ Blood cells, most notably platelets, also contribute to the formation of a blood clot. Once in contact (c) 2021. Thieme. All rights reserved. Georg Thieme Verlag KG,

Rüdigerstraße 14,

70469 Stuttgart, Germany
DOI https://doi.org/ 10.1055/a-1450-8300. ISSN 0340-6245. 
with subendothelial collagen, platelets get activated, form aggregates and expose procoagulant surfaces to support thrombin generation (TG). ${ }^{19-21}$

Assessment of blood coagulability is essential for the clinical management of replacement therapy or anticoagulation in the settings of haemophilia or thrombophilia, respectively. Traditionally, this was done primarily by monitoring fibrin clot formation after TG is initiated with high concentrations of extrinsic or intrinsic activators through prothrombin time (PT) or activated partial thromboplastin time (APTT) measurements. ${ }^{22,23} \mathrm{~A}$ limitation of testing fibrin formation is that it occurs at very low levels $(\sim 5 \%)$ of thrombin formation, ${ }^{24,25}$ whereas important physiological information after the TG initiation phase is not represented. Indeed, PT and APTT are insensitive to changes in the anticoagulant pathways, and are therefore not indicative for thrombotic risks caused by anticoagulant pathway impairment. ${ }^{25}$

In contrast to PT and APTT, TG assays (TGAs) are usually initiated with low concentrations of TF, and report the full process of thrombin activation and inactivation. Furthermore, TG can be further optimized for specific pathway testing such as the protein $\mathrm{C}$ pathway by addition of thrombomodulin. ${ }^{26,27}$ Nowadays, TG is mainly tested in plateletpoor plasma (PPP-TG), with exogenous synthetic phospholipid vesicles added to mimic the physiologic procoagulant surfaces. Although PPP-TG gives, in many aspects, deeper insights into coagulation than PT and APTT, it does not represent the involvement of blood cells, such as the platelets, erythrocytes and leukocytes. By testing TG in plateletrich plasma (PRP-TG), many influences of platelets on coagulation have been revealed (vide infra). However, the impact of other cells is still unclear, primarily due to the lack of assessment tools. In this review, we discuss currently available TGAs, especially those capable of testing TG in the presence of blood cells (i.e., in PRP or whole blood [WB]). In addition, we summarize the effects of blood cells on coagulation and highlight the direct influences of these cells on TG testing. Advantages and limitations of these blood celldependent TG tests will also be discussed.

\section{PPP-TGA: Principle, Advantage and Pitfalls}

\section{History and Principle of TG Assays}

TGA was pioneered in 1953 by Macfarlane and Biggs, ${ }^{28}$ who subsampled an activated blood sample at regular time intervals into test tubes containing fibrinogen, and then calculated the thrombin activity at each time point by comparing the respective clotting time with a calibration curve. The time- and labour-consuming nature of the assay was drastically improved in 1993 by Hemker et al through the introduction of a slow-reacting chromogenic thrombin substrate, which allowed thrombin activity to be continuously measured by monitoring the cleavage of the substrate, without the need for timed subsampling. ${ }^{29}$ Although chromogenic methods allow continuous TG measurement, fibrin formation in plasma needs to be prevented to avoid disturbance on optical density detection. This is usually done by defibrinating PPP or by adding an inhibitor of fibrin polymerization into the test; both are known to influence TG. ${ }^{30,31}$ Hemker and colleagues solved this problem by introducing a fluorogenic thrombin substrate that is not disturbed by fibrin formation (- Fig. 1). ${ }^{32,33}$ Issues related to fluorescence monitoring, such as the inner filter effect, substrate consumption or the influence of the colour of plasma on fluorescence, were solved by introducing a parallel calibration experiment in which substrate cleavage by the $\alpha_{2}-$ macroglobulin-thrombin complex with a constant thrombin activity in the same plasma is recorded. ${ }^{32,34} \mathrm{~A}$ dedicated $\mathrm{H}$-transform algorithm was developed to calibrate against the above-mentioned issues to allow objective calculation. ${ }^{35}$ This fluorogenic TGA is commercially known as the Calibrated Automated Thrombography (CAT) which allows relatively fast and high throughput measurement of up to 48 samples per run in PPP and PRP, a tremendous improvement compared with the subsampling method of 1 man-hour per curve. ${ }^{32,34}$

Currently, there are several commercially available semiautomated chromogenic TGAs, ${ }^{36}$ including HemoScan Thrombin Generation Assay (HemoScan), Pefakit in-TDT (Pentapharm) and Innovance ETP (Siemens Healthcare). Semi-automated fluorogenic TGAs include Technothrombin-TGA (Technoclone) and CAT (Diagnostica Stago). There are also two fully automated fluorogenic TGAs: the CEVERON-TGA (Technoclone) and ST-Genesia (Diagnostica Stago).

\section{Thrombogram Parameters}

The whole course of prothrombin conversion and thrombin inactivation over time is shown as a thrombogram, which is typically characterized by five parameters (- Fig. 1B). The time needed for thrombin to reach a detectable concentration is defined as lag time. The highest transient thrombin concentration during the reaction is referred to as peak height, and the time needed to reach this peak is called time to peak. Velocity index (VI) can be obtained by dividing peak height by the difference between time to peak and lag time. Finally, the area under the TG curve, which represents the total amount of thrombin activity during the reaction, is termed endogenous thrombin potential (ETP).

\section{Clinical Utilities of PPP-TG}

The clinical utility of PPP-TG A has been extensively explored and reviewed in detail elsewhere. ${ }^{25,37,38}$ In brief, the PPP-TG parameters have been shown to be predictive of the risk of idiopathic venous thromboembolism (VTE) $)^{39}$ and VTE recurrence, ${ }^{40}$ as well as the amount of blood loss after cardiac surgery. ${ }^{41}$ TGAs also have the potential to serve as a laboratory tool to monitor replacement therapy in haemophilia ${ }^{42}$ or anticoagulant treatments. ${ }^{43}$ In addition, TGAs are useful tools for exploring novel mechanisms of haemostasis or thrombosis. For example, thrombomodulin- or APC-modified TGAs were essential tools for the establishment of prothrombotic effect of oral contraceptive pills, ${ }^{44,45}$ as well as the rebalanced pro- and anticoagulant coagulation system in liver disease. ${ }^{26,46}$ 


\section{A. Schematic illustration of a continuous thrombin generation measurement}

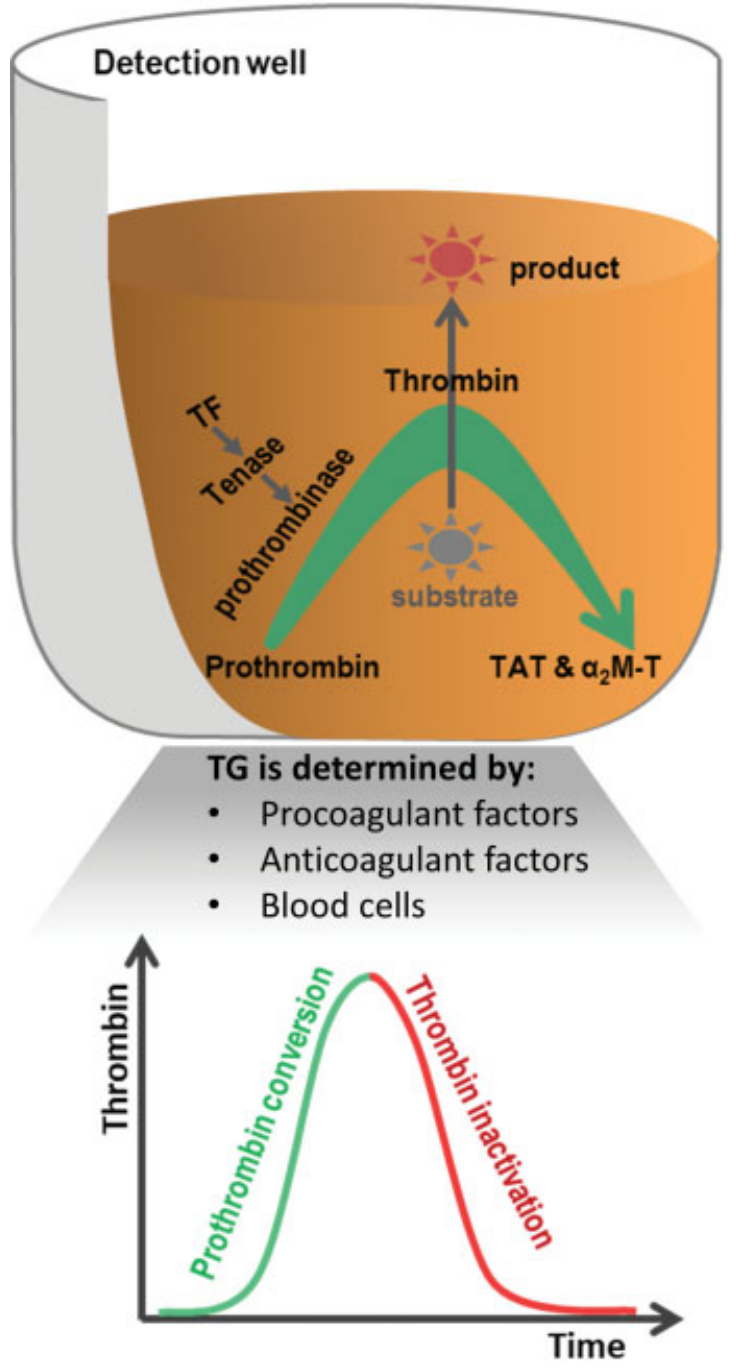

\section{B. From fluorescence signals to a thrombogram}
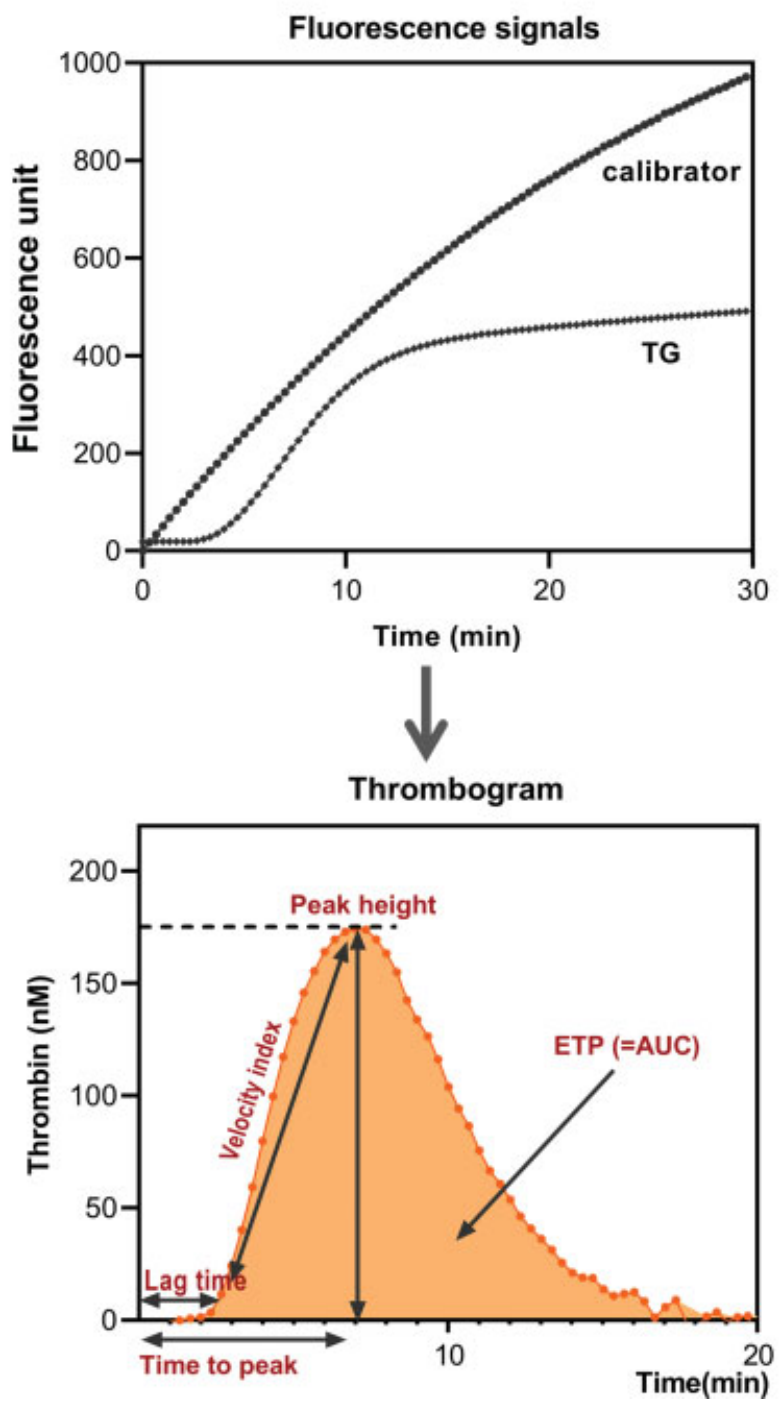

Fig. 1 Overview of the thrombin generation (TG) assay. (A) A schematic illustration of fluorogenic TG assays. After coagulation is triggered with tissue factor (TF) in a recalcified blood sample, the complex interactions between pro- and anticoagulant factors as well as blood cells lead to prothrombin conversion. The generated thrombin cleaves a fluorogenic thrombin substrate and result in an increase in fluorescence signal. Thrombin is inactivated by its natural inhibitors in blood into antithrombin-thrombin (TAT) and $\alpha_{2}$-macroglobulin-thrombin $\left(\alpha_{2} \mathrm{M}-\mathrm{T}\right)$ complexes. (B) The fluorescence signals of TC experiments are used to generate a thrombogram, which can be characterized by the so-called TG parameters, including lag time, time to peak, thrombin peak, velocity index and endogenous thrombin potential (ETP; i.e., the area under the TG curve [AUC]).

\section{Limitations of PPP-TG Assays}

In the early development phase of the TGA, there were major concerns about the high inter-centre variation of PPP-TG, which render the assay not suitable for clinical laboratories. Later, it was shown that acceptable imprecision can be obtained given that standardized reagents and good thermal control are guaranteed, and that pre-analytical conditions, including blood collection method, the use of a contact pathway inhibitor, transportation method, storage time and centrifugation protocol, are standardized. ${ }^{47-51}$ The use of a reference plasma to normalize the TG parameters further improved the inter-laboratory variation. ${ }^{52,53}$ Recently introduced fully automated TG testing systems are good tools for standardized TG and are expected to bring TG to the routine repertoire of tests conducted in haemostasis centres.
Despite the above-mentioned improvements, PPP-TGA still has some limitations (summarized in -Table 1). One major limitation of PPP-TG is that the physiological procoagulant surfaces, that is, blood cells, are not available in plasma, while instead synthetic phospholipids are used at saturated concentration to resemble the function of blood cells. As a result, the blood cell-dependent variations between individuals are not studied with this method. It is now widely established that physiological haemostasis follows a cell-based model, instead of the classical models which divide haemostasis into primary and secondary haemostasis. ${ }^{14,54}$ The cell-based model describes a three-phase interplay between blood cells and TG. First, TF-bearing cells initiate TG and lead to the activation of a small amount of thrombin (i.e., the initiation phase). Thrombin then activates 
Table 1 Characteristics of TG in PPP, PRP and WB

\begin{tabular}{|l|l|l|l|}
\hline \multirow{5}{*}{ Advantage } & PPP-TG & PRP-TG & WB-TG \\
\hline & $\begin{array}{l}\text { Commercially available } \\
\text { semi-automated assays } \\
\text { and fully automated assays }\end{array}$ & $\begin{array}{l}\text { Commercially available semi-auto- } \\
\text { mated assays }\end{array}$ & $\begin{array}{l}\text { Includes all circulating cells and } \\
\text { therefore reflects the influences of } \\
\text { these cells on TG }\end{array}$ \\
\cline { 2 - 4 } & High throughput & $\begin{array}{l}\text { Reflects the influence of platelet } \\
\text { dysfunction on TG }\end{array}$ & $\begin{array}{l}\text { Less influenced by pre-analytical var- } \\
\text { iations than plasma tests }\end{array}$ \\
\cline { 2 - 4 } & Good standardization & $\begin{array}{l}\text { Reflects the influence of some } \\
\text { platelet-associated factors (e.g., } \\
\text { VWF, FXI) }\end{array}$ & $\begin{array}{l}\text { Fast measurement (potential for } \\
\text { point-of-care use) }\end{array}$ \\
\cline { 2 - 4 } & $\begin{array}{l}\text { Blood cells are omitted in } \\
\text { the test, thus not possible } \\
\text { to study cell-mediated } \\
\text { thrombosis or bleeding }\end{array}$ & $\begin{array}{l}\text { Erythrocytes, leucocytes (and can- } \\
\text { cer cells) are omitted }\end{array}$ & $\begin{array}{l}\text { There is no commercial assay or } \\
\text { standardized reagent }\end{array}$ \\
\cline { 2 - 4 } & $\begin{array}{l}\text { Centrifugation is needed to } \\
\text { prepare PPP from WB, } \\
\text { therefore has a long turn- } \\
\text { around time }\end{array}$ & $\begin{array}{l}\text { Pre-analytical variations during PRP } \\
\text { preparation and long turnaround } \\
\text { time }\end{array}$ & $\begin{array}{l}\text { Lack of standard sample for normali- } \\
\text { zation and influence of blood flow or } \\
\text { endothelium is not included }\end{array}$ \\
\cline { 2 - 4 } & $\begin{array}{l}\text { Influence of blood flow or } \\
\text { endothelium are not } \\
\text { included }\end{array}$ & $\begin{array}{l}\text { Lack of standard sample for nor- } \\
\text { malization and influence of blood } \\
\text { flow or endothelium is not included }\end{array}$ & \\
\hline
\end{tabular}

Abbreviations: FXI, factor XI; PPP, platelet-poor plasma; PRP, platelet-rich plasma; TG, thrombin generation; VWF, von Willebrand factor; WB, whole blood.

platelets to expose phosphatidylserine, as well as activating FXI, FV and FVIII (the amplification phase); these processes prepare necessary procoagulant surface and reactants to allow a burst of thrombin formation during the 'propagation phase'. The influence of blood cells on TG is not limited to providing phospholipids, but includes many other mechanisms (-Fig. 2). TGA that includes blood cells, either in PRP or in WB, may be useful for studying the cellular influences in coagulation disorders and may allow more comprehensive coagulation profiling.

\section{PRP-TGAs and the Influence of Platelets on TG}

PRP-TG was first explored by subsampling methods, ${ }^{28}$ which, although was time- and labour-consuming, provided early evidences for a role of platelets in TG. ${ }^{55}$ The fluorogenic assays largely avoid unwanted platelet activation caused by frequent subsampling and are now the most widely used method in the field.

\section{Influence of Platelet Granule Secretion on PRP-TG}

Platelets possess two kinds of storage organelles, the $\alpha$ granules and dense granules. The contents of these granules are released to the surrounding environment upon platelet activation. $^{56,57}$ Polyphosphates, stored in platelet-dense granules, may enhance the activation of FV and FXI by thrombin. In addition, it was also reported that polyphosphate nanoparticles released onto the platelet surface cause the (auto)activation of FXII, thus potentially enhancing TG and fibrin clot formation. ${ }^{58,59}$ Coagulation factors secreted from the $\alpha$-granules, including FV, prothrombin, fibrinogen, von Willebrand factor (VWF), high molecular weight kininogen and FXIII, promote TG and fibrin clot formation.
Platelets also secrete anticoagulant proteins such as TF pathway inhibitor (TFPI), protease nexin-1and protein $S$. It was shown that $\sim 62 \%$ of plasma-free TFPI $\alpha$ are stored in platelets, and TFPI $\alpha$ released from platelets were able to diminish plasma TG. ${ }^{60}$ In addition, activated platelets induce APC resistance in TG testing via the release of platelet factor 4 $(\mathrm{PF} 4)^{61}$ and a special pool of FV(a) ${ }^{62}$ from their $\alpha$-granules. Furthermore, several independent groups have shown that platelets store in their $\alpha$-granules considerable amounts of $\mathrm{TF}^{10}$ that are originated from megakaryocytes ${ }^{63}$ or by de novo synthesis using mRNA templates. ${ }^{64}$ Both the antigen and the procoagulant activity of TF have been detected on platelets, ${ }^{8,65}$ although Østerud and Olsen and Bouchard et al contradicted these findings, ${ }^{66-69}$ likely due to methodological differences. ${ }^{70,71}$

Platelet granular contents have been shown to influence TG. An illustrating example was found in FV-deficient patients who have no detectable plasma FV and PPP-TG, in which the absence of life-threatening bleedings could be explained by FV contribution from platelets leading to sufficient PRP-TG. ${ }^{72}$ In addition, in patients with Quebec platelet disorder (QPD), who have defects in $\alpha$-granule proteins including FV due to the presence of excessive $\alpha$-granule urokinase-type plasminogen activator levels, normal PPPTG profile but defective PRP-TG were found, and the lower ETP and peak thrombin in PRP showed a strong association with platelet FV level, ${ }^{73}$ further supporting a notable impact of platelet-derived FV on TG.

\section{Influence of Platelet-coagulation Factor Binding on PRP-TG}

Besides phosphatidylserine, several platelet membrane receptors can also bind coagulation factors and localize 


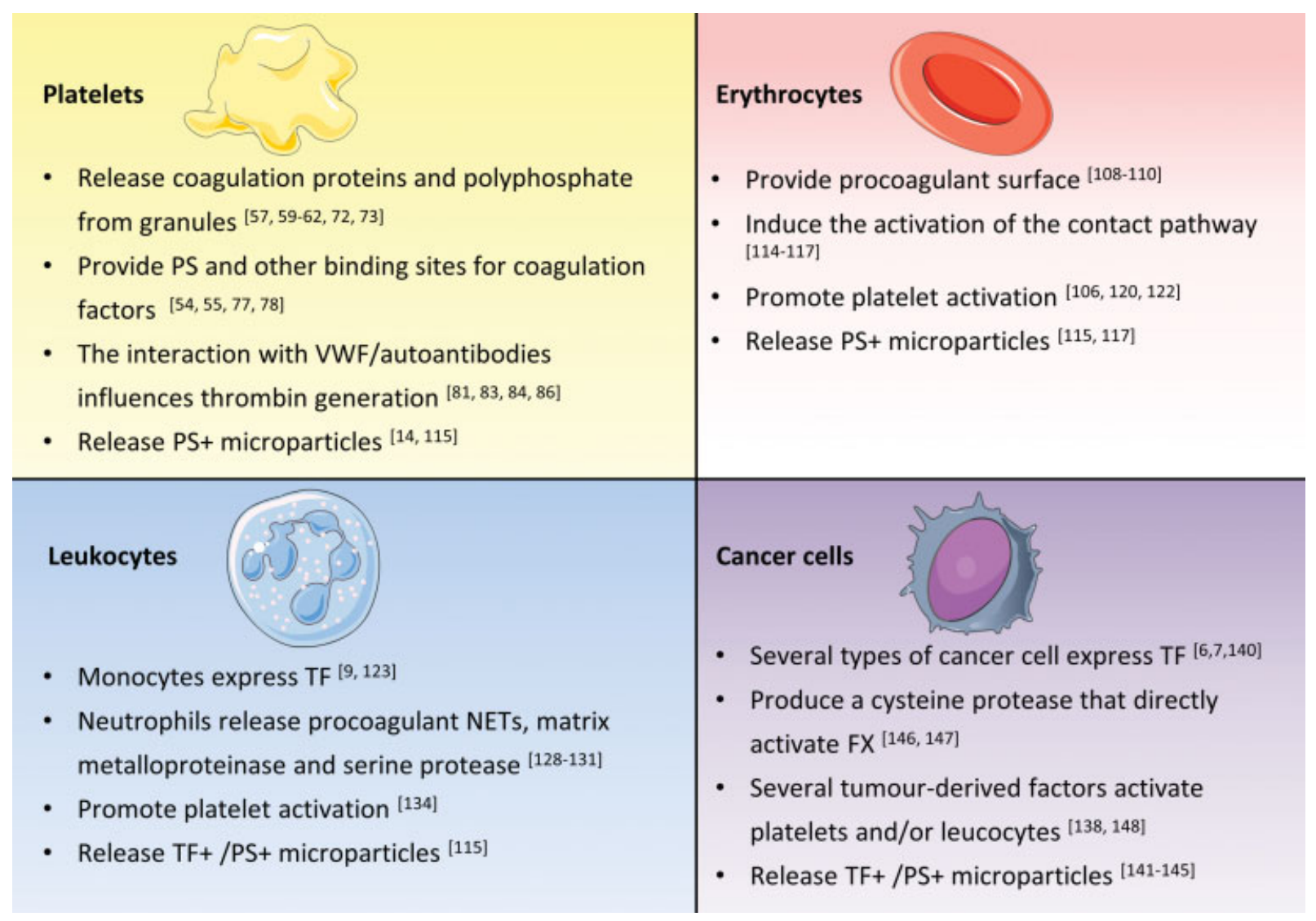

Fig. 2 Brief summary of the influence of blood cells on thrombin generation (TG). Blood cells affect TG through many mechanisms, including the exposure of procoagulant phosphatidylserine (PS), releasing of granule contents, production of PS-positive and/or tissue factor (TF) positive microparticles, or through the localization of coagulation factors to membrane receptors, etc. (NETs, neutrophil extracellular traps; VWF, von Willebrand factor; FX, factor X.).

coagulation factors to the procoagulant surface, thus modifying the kinetics of TG. ${ }^{54}$ For example, glycoprotein (GP) IbV-IX binds VWF and brings VWF-bound FVIII to the platelet membrane. Integrin $\alpha_{\mathrm{II}} \beta_{3}$, the most abundant receptor on platelets, binds fibrinogen and VWF in its active conformation. Furthermore, FXI is a ligand for apolipoprotein E receptor 2 (ApoER2) on platelets and thrombin is recognized by both GP Ib-V-IX and protease-activated receptors (PARs). There is also functional evidence suggesting the existence of receptors for FVIII, FIX and FX on the platelet surface. ${ }^{54}$

The binding of coagulation factors to platelets can modify TG. Platelet inhibition in vitro by either blocking membrane receptors (e.g., $\alpha_{I I} \beta_{3}$ blockage by abciximab) or blocking procoagulant surface (e.g., annexin $\mathrm{V}$ ) leads to decreased peak and ETP of PRP-TG. ${ }^{74,75}$ Glanzmann's thrombasthenia or Bernard-Soulier syndrome, bleeding disorders due to deficiencies in platelet $\alpha_{\mathrm{IIb}} \beta_{3}$ or GPIb $\alpha$, respectively, reduces the amount of thrombin generated in PRP. ${ }^{55,76,77}$ Further evidence of a regulating role of platelets in TG is the finding that the bleeding phenotype in patients with FXI deficiency can be better differentiated by measuring TG in PRP than PPP-TG testing. ${ }^{78,79}$ This observation implies the importance of physiological-relevant interactions between platelets and FXI during the amplification phase of TG, and suggests that PRP-TG could be a potential diagnostic tool in this setting.

\section{Influence of Platelet-VWF Binding on PRP-TG}

In primary haemostasis, VWF is an essential mediator for platelet adhesion and aggregation. Normally, VWF circulates in an inactive coiled conformation, but upon exposure to subendothelial collagen, VWF exposes its A1 domain and is able to bind platelet GPIb, which subsequently induces platelet activation. ${ }^{80}$ Pelkmans et $\mathrm{al}^{81}$ showed that TG in the presence of platelets is sensitive to the activation status of VWF. They reported that a recombinant VWF variant (VWF-2B), which has a gain-of-function mutation in the VWF A1 domain that corresponds to mutations in type IIB VWD, was able to augment PRP-TG presumably because VWF-2B induced spontaneous platelet activation via GPIb. In addition, when TG was tested in reconstituted PRP by adding washed normal platelets resuspended in PPP from VWD-2B patients or controls, the ratio of ETP in PRP-to-ETP in PPP was higher with patient plasma than that of controls, demonstrating that the procoagulant effect of VWF-2B is platelet dependent.

VWF also mediates the translocation of FVIII from solution to platelet surface and therefore modulates TG on platelet surface. Patients with quantitative or functional defects in VWF have an increased risk of bleeding, but this phenotype is not always explained by the degree of VWF deficiency. ${ }^{82}$ Rugeri et al studied TG in a group of patients with various 
types of von Willebrand disease (VWD) and found that these patients had markedly reduced ETPs and peak heights in PPP. ${ }^{83}$ Interestingly, in PRP-TG they found comparable ETPs with a significantly decreased peak height. The low FVIII level in these patients seemed to be the major cause of defect in TG peak height, because FVIII supplementation was able to restore TG in both PPP and PRP, but VWF supplementation in the presence of normal FVIII level did not influence TG. Recently, Szanto et al reproduced the above results in a group of patients with type $3 \mathrm{VWD}$ (absence of VWF) in which they found diminished PPP-TG (lower peak and ETP) but overall comparable ETP and 13\% decreased peak height in PRP-TG compared with healthy controls. ${ }^{84}$ The reason behind the discrepancy between ETP and peak height of PRP-TG in VWD patients is still unclear, but Szanto et al ${ }^{84}$ attribute the normal ETP in type 3 VWD to the compensatory role played by hyper-responsive platelets. Additional evidences are required to establish whether ETP or peak height of PRP-TG is more useful in predicting the bleeding risk in these patients, but Rugeri et al ${ }^{83}$ found that a sub-threshold peak height was associated with a higher bleeding score in these patients, and argued that the ETP is not the only important parameter of the thrombogram.

Influence of Platelet-autoantibody Binding on PRP-TG Autoantibodies against platelets can be generated due to immune disorders (immune thrombocytopenic purpura or systemic lupus erythematosus) or secondary to viral infections, as well as upon vaccination or administration of certain drugs. ${ }^{85}$ Heparin-induced thrombocytopenia (HIT) is a rare but severe complication caused by autoantibodies against the heparin-PF4 complex during heparin therapy and these antibodies cause spontaneous activation and accelerated clearance of platelets. Tardy-Poncet et $\mathrm{a}^{86}$ recapitulated the hypercoagulable state in these patients by showing that HIT antibody-positive PPP reacts stronger (higher peak height) to suppletion of unfractionated heparin than HIT-negative PPP after the plasmas were mixed with PRP of normal controls, thus demonstrating that HIT antibodies were able to potentiate platelet-dependent TG. Remarkably, they also showed that a HIT thrombogram profile defined by three ratios with/without heparin of TG parameters (peak, VI and time to peak) allowed sensitive identification (22 out of 23) of HIT-positive patients without false positive, suggesting PRP-TG might have a place in the diagnosis of HIT.

\section{Influence of Platelet Number and Size on PRP-TG}

Normal platelet count in humans is between 150 and $450 \times 10^{9} / \mathrm{L}$, and altered numbers have been seen in thrombocytopenia and thrombocythemia. Studies on the influence of platelet counts on PRP-TG using reconstituted PRPs have shown that platelet counts correlate with TG acceleration if the platelet numbers are below $100 \times 10^{9} / \mathrm{L}$ : increasing platelet counts reduce the lag time of TG and increase the peak thrombin level and ETP. ${ }^{32,74,87}$ If the platelet numbers are above $100 \times 10^{9} / \mathrm{L}$, then platelet numbers still correlate with the peak height, but the ETP becomes independent of the numbers. Currently, to control the pre-analytical varia- tion of platelet count introduced during PRP preparation, platelet-dependent TG is often tested with platelet count adjusted to $150 \times 10^{9} / \mathrm{L}^{51}$ but this may mask the impact of individual platelet count differences, especially in patients with thrombocytopenia.

In the population-based Gutenberg Health Study which studied PRP-TG profile of $\sim 400$ individuals, mean platelet volume (MPV, a measure of platelet size) and platelet count were both independent determinants of PRP-TG parameters. ${ }^{88}$ Increased platelet count and MPV were both related to shorter lag time and increased peak height. Platelet count was also significantly associated with increased ETP. Consistent with the above observation, increased MPV was related to higher platelet reactivity and was shown to be predictive of stroke and atrial fibrillation. ${ }^{89}$ It was also shown that larger platelets $(\mathrm{MPV}=\sim 11 \mathrm{fL})$ express threefold higher levels of TF compared with smaller counterparts (MPV $=\sim 7$ $\mathrm{fL})^{70}$

Thrombocytopenia is a common complication of liver cirrhosis, with a prevalence of thrombocytopenia between 15 and $75 \% .^{90}$ Tripodi et al studied thrombomodulin-modified TG with different counts of platelets in cirrhotic patients and found that the ETP of these patients was lower than controls if platelet counts were adjusted to their WB level, but became comparable to normal controls if the platelet count was adjusted to $100 \times 10^{9} / \mathrm{L} .{ }^{91}$ They also showed that ETP was positively correlated with platelet counts and estimated that a minimum of $56 \times 10^{9} / \mathrm{L}$ platelet is required to guarantee sufficient TG.

\section{PRP-TG Assays: Advantages and Limitations}

PRP-TG is of additional value to PPP-TG because it gives insight into the role of platelets in coagulation and in the interplay between platelets and coagulation (summarized in -Tables $\mathbf{1}$ and 2). This may give insight into coagulation complications in platelet-related disorders.

Similar to PPP-TG, PRP-TG is performed under near-static conditions, so the impact of blood flow on the interaction between platelets and VWF or other coagulation protein is lacking. Furthermore, although the addition of thrombomodulin can partly resemble the anticoagulant function of endothelial cells, they also synthesize and release other coagulation proteins, most notably TFPI and VWF. The representation of endothelial function is also complexed by the fact that these proteins/receptors are differentially expressed across different vascular beds and are altered post-activation. ${ }^{92}$

It is also noteworthy that PRP-TG still needs further standardization to be clinically applicable. Although the existence of commercial assay systems ${ }^{32}$ and expert recommendations ${ }^{48,51}$ ensure acceptable within-laboratory reproducibility, it may still suffer from large inter-centre variations because of the lack of standardization of preanalytical conditions between laboratories. ${ }^{93}$ Because platelets are activated during long time storage, currently there is no established standardized PRP sample for PRP-TG results normalization. ${ }^{94}$ As a result, comparison of results between different centres is still troublesome. The requirement that 
Table 2 Platelet-dependent thrombin generation tested in humans

\begin{tabular}{|c|c|c|c|c|c|}
\hline Study & $\begin{array}{l}\text { Tested population } \\
\text { and main charac- } \\
\text { teristics }\end{array}$ & TG method & PPP-TG result & PRP-TG result & $\begin{array}{l}\text { Platelet-related me- } \\
\text { chanism }\end{array}$ \\
\hline Duckers et $\mathrm{al}^{72}$ & $\begin{array}{l}\text { Patients with se- } \\
\text { vere congenital } \\
\text { factor } V \text { deficiency }\end{array}$ & $\begin{array}{l}\text { CAT; various TF } \\
\text { concentrations } \\
\text { and } 20-\mu M \text { PL (PPP- } \\
\text { TG); various TF } \\
\text { concentrations } \\
\text { (PRP-TG) }\end{array}$ & $\begin{array}{l}\text { Lower or even } \\
\text { undetectable } \\
\text { TG in patients } \\
\text { compared } \\
\text { with controls }\end{array}$ & $\begin{array}{l}\text { Adequate TG when } \\
\text { platelets were pre- } \\
\text { activated }\end{array}$ & $\begin{array}{l}\text { Residual platelet FV } \\
\text { and low TFPI level to- } \\
\text { gether ensured an } \\
\text { adequate TG }\end{array}$ \\
\hline Brunet et $\mathrm{al}^{73}$ & $\begin{array}{l}\text { Patients with Que- } \\
\text { bec platelet disor- } \\
\text { der (increased uPA } \\
\text { in platelets) }\end{array}$ & 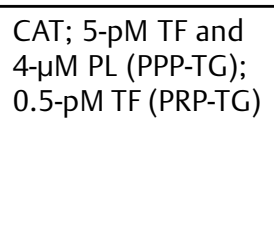 & $\begin{array}{l}\text { Comparable } \\
\text { ETP and peak } \\
\text { height be- } \\
\text { tween } \\
\text { patients and } \\
\text { controls }\end{array}$ & $\begin{array}{l}\downarrow \text { ETP and peak } \\
\text { height in patients }\end{array}$ & $\begin{array}{l}\text { Decreased platelet } \alpha \\
\text { granule FV, due to } \\
\text { exceptionally high } \\
\text { kallikrein activity in } \\
\text { platelets }\end{array}$ \\
\hline Béguin et al ${ }^{77}$ & $\begin{array}{l}\text { Patients with Ber- } \\
\text { nard-Soulier syn- } \\
\text { drome (GPIb } \\
\text { deficiency) }\end{array}$ & CAT; 0.5-pM TF & None & $\begin{array}{l}\downarrow \text { ETP and peak } \\
\text { height in patients } \\
\text { compared with } \\
\text { control }\end{array}$ & $\begin{array}{l}\text { GPIb deficiency or in- } \\
\text { hibition (in normals) } \\
\text { reduces TG in a fibrin- } \\
\text { dependent manner }\end{array}$ \\
\hline Reverter et al $^{55}$ & $\begin{array}{l}\text { Patients with } \\
\text { Glanzmann's } \\
\text { thrombasthenia } \\
\text { (integrin } \alpha_{11 b} \beta_{3} \\
\text { deficiency) }\end{array}$ & $\begin{array}{l}\text { Subsampling; un- } \\
\text { known TF; platelets } \\
\text { of Glanzmann's } \\
\text { thrombasthenia } \\
\text { resuspended in } \\
\text { normal PPP }\end{array}$ & None & $\begin{array}{l}\downarrow \text { ETP and peak } \\
\text { height with patient } \\
\text { platelets com- } \\
\text { pared with normal } \\
\text { platelets }\end{array}$ & $\begin{array}{l}\alpha_{\text {IIb }} \beta_{3} \text { deficiency or } \\
\text { inhibition (in nor- } \\
\text { mals) reduces TG }\end{array}$ \\
\hline Pelkmans et al ${ }^{81}$ & $\begin{array}{l}\text { Patients with type } \\
\text { IIB von Willebrand } \\
\text { disease (VWF-2B } \\
\text { variant, a gain-of- } \\
\text { function mutation } \\
\text { in the VWF A1 } \\
\text { domain) }\end{array}$ & $\begin{array}{l}\text { CAT; 1- or 5-pM TF } \\
\text { (PRP-TG) }\end{array}$ & $\begin{array}{l}\text { Tested, but } \\
\text { exact num- } \\
\text { bers and } \\
\text { comparison } \\
\text { between } \\
\text { patients and } \\
\text { controls not } \\
\text { shown }\end{array}$ & $\begin{array}{l}\text { } \text { ETP and peak af- } \\
\text { ter adding VWF-2B } \\
\text { into normal PRP; } \\
\text { normal platelets } \\
\text { added into patient } \\
\text { plasma had } \uparrow \mathrm{TG} \\
\text { than added into } \\
\text { normal plasma }\end{array}$ & $\begin{array}{l}\text { Incubation of plate- } \\
\text { lets with VWF-2B } \\
\text { resulted in a fivefold } \\
\text { increased exposure of } \\
\text { phosphatidylserine } \\
\text { and a threefold in- } \\
\text { creased expression of } \\
\text { P-selectin }\end{array}$ \\
\hline $\begin{array}{l}\text { Rugeri et al } \\
\text { and Szanto et al }\end{array}$ & $\begin{array}{l}\text { Patients with von } \\
\text { Willebrand's dis- } \\
\text { ease (type } 1,2 \\
\text { and/or 3) }\end{array}$ & 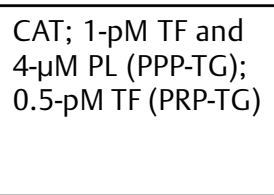 & $\begin{array}{l}\downarrow \text { ETP and } \\
\text { peak height } \\
\text { in patients } \\
\text { compared } \\
\text { with control }\end{array}$ & $\begin{array}{l}\downarrow \text { peak height, but } \\
\text { comparable ETP }\end{array}$ & $\begin{array}{l}\text { Enhanced platelet ac- } \\
\text { tivation markers in } \\
\text { flow cytometric assay }\end{array}$ \\
\hline $\begin{array}{l}\text { Tardy- } \\
\text { Poncet et al }\end{array}$ & $\begin{array}{l}\text { Patients with hep- } \\
\text { arin-induced } \\
\text { thrombocytopenia } \\
\text { (HIT; autoantibody } \\
\text { against PF4-hepa- } \\
\text { rin complex) }\end{array}$ & $\begin{array}{l}\text { CAT; TF concentra- } \\
\text { tion unclear and } \\
\pm 0.2 \mathrm{U} / \mathrm{mL} \text { UFH } \\
\text { (PRP-TG); mixing } \\
\text { patient PPP with } \\
\text { PRP from normals }\end{array}$ & None & $\begin{array}{l}\text { 个ratio of ETP, peak } \\
\text { height and VI (- } \\
\text { with/without hep- } \\
\text { arin) in HIT- } \\
\text { positive than in } \\
\text { HIT-negative } \\
\text { plasma }\end{array}$ & $\begin{array}{l}\text { HIT antibody-induced } \\
\text { platelet activation, } \\
\text { which could be abol- } \\
\text { ished by blocking } \\
\text { FcyRlla receptor }\end{array}$ \\
\hline $\begin{array}{l}\text { Panova- } \\
\text { Noeva et al }\end{array}$ & $\begin{array}{l}407 \text { adults from } \\
\text { the population- } \\
\text { based Gutenberg } \\
\text { Health Study }\end{array}$ & 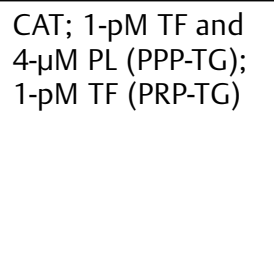 & $\begin{array}{l}\text { No } \\
\text { comparison }\end{array}$ & No comparison & $\begin{array}{l}\text { Platelet count and } \\
\text { MPV are independent } \\
\text { determinants of ETP } \\
\text { and peak height of } \\
\text { PRP-TG in multivari- } \\
\text { able linear regression } \\
\text { analysis }\end{array}$ \\
\hline Tripodi et al ${ }^{91}$ & $\begin{array}{l}\text { Cirrhotic patients } \\
\text { (reduced pro- and } \\
\text { anticoagulant fac- } \\
\text { tors and thrombo- } \\
\text { cytopenia) }\end{array}$ & 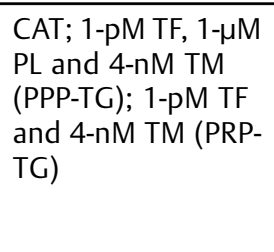 & $\begin{array}{l}\text { Comparable } \\
\text { ETP between } \\
\text { patients and } \\
\text { healthy con- } \\
\text { trols; peak } \\
\text { height not } \\
\text { shown }\end{array}$ & $\begin{array}{l}\downarrow \text { ETP when PRP } \\
\text { has physiological } \\
\text { platelet count; but } \\
\text { normal ETP when } \\
\text { platelet count was } \\
\text { adjusted to } \\
100 \times 10^{9} / \mathrm{L}\end{array}$ & $\begin{array}{l}\text { Platelet count of } \\
56 \times 10^{9} / \mathrm{L} \text { is needed } \\
\text { to guarantee suffi- } \\
\text { cient TG }\end{array}$ \\
\hline
\end{tabular}

Abbreviations: CAT, calibrated automated thrombogram; ETP, endogenous thrombin potential; FV, factor V; GPIb, glycoprotein Ib; MPV, mean platelet volume; PF4, platelet factor 4; PL, phospholipids; PPP, platelet-poor plasma; PRP, platelet-rich plasma; TF, tissue factor; TG, thrombin generation; TM, thrombomodulin; UFH, unfractionated heparin; UPA, urokinase plasminogen activator. 
PRP needs to be tested within a short time (6 hours if blood is collected with corn trypsin inhibitor [CTI] and 2 hours if not $^{49}$ ) also raises logistic issues for large-scale multicentre studies, which are currently needed to evaluate the real clinical value of this technique.

\section{WB-TGAs and the Influence of Erythrocytes, Leukocytes and Cancer Cells}

In contrast to platelets whose role in coagulation has been well established, little is known about the involvement of other circulating blood cells in coagulation and TG. WB-TGA is a promising solution to study the interplay between all blood cells and coagulation in relation to thrombotic and bleeding complications. There are some studies about the influence of erythrocytes on TG, but other blood cells such as leukocytes and cancer cells remain largely unexplored.

\section{WB-TG Assays: Technical Challenges and Recent Advances}

Although TG with the subsampling technique can be applied to all blood preparations including $\mathrm{WB}$, it has major drawbacks: it is time- and labour-consuming. Furthermore, this method only measures active thrombin in free solution but not those bound to fibrin. ${ }^{32}$ Alternatively, an enzyme-linked immunosorbent assay (ELISA) based assay was developed to quantify the thrombin-antithrombin (TAT) complex in timed subsamples from clotting WB. ${ }^{95}$ This assay allows indirect estimation of TG but is still time-consuming. An electrochemical TGA for plasma and WB has also been introduced in $2009,{ }^{96}$ but was not reproduced in any further studies. Continuous chromogenic TGAs cannot be applied in WB because erythrocytes seriously disturb optical measurement.

Fluorogenic TGAs allow continuous and high throughput TG measurements in plasma, but their application in WB has been challenging. Erythrocytes sediment and contract with clot during TG measurement, which may cause variable quenching of the fluorescent signal over time and lead to erratic signals. ${ }^{97,98}$ Several methods have been previously presented to solve this problem. In 2007, Tappenden et $\mathrm{al}^{97}$ reported a method in which an orbital shake was applied to the assay plate during the idle time between two rounds of readings, but this method still gave rather high variations. Ninivaggi et al $^{99}$ later reported another approach which utilizes a filter paper matrix to restrain the erythrocytes in a thin layer to avoid erythrocyte sedimentation. This technique yields reproducible results, but requires good level of pipetting to guarantee reproducibility. ${ }^{100}$ In 2016, Kelchtermans et al reported a rheometer-based fluorogenic assay for simultaneous measurement of TG and fibrin formation in PPP and $\mathrm{WB},{ }^{30}$ in which the issue of erythrocyte sedimentation was minimized by constantly mixing the blood with the rotation of the cone in the rheometer. A major disadvantage of this procedure is the low sample throughput: only one sample can be measured per run. Recently, we developed a novel fluorogenic TGA for WB measurements in which erythrocyte sedimentation is prevented by a continuous mixing induced by maintaining a continuous movement of the assay plate. ${ }^{87}$ This assay has good reproducibility while requiring less handling than the filter paper-based assay.

\section{Influence of Erythrocytes Phosphatidylserine and Number on WB-TG}

Until recently, erythrocytes have been considered passive bystanders in coagulation and are often omitted in coagulation tests. However, clinical abnormalities in both erythrocyte quantity (elevated haematocrit) and quality (e.g., sickle cell disease [SCD], thalassemia) have been associated with arterial and venous thrombosis. ${ }^{101-105}$ Causality of this relation has not been determined, although it was speculated that altered blood rheology, caused by the elevated haematocrit, altered erythrocyte deformability and the formation of erythrocyte aggregates (rouleaux), could reduce the velocity of blood flow, diminish the anti-adhesive effect of endothelium-derived nitric oxide (NO) and increase the migration/adhesion of platelets to the vessel walls. ${ }^{101,102,106,107}$ Apart from the above-mentioned mechanism, a subset of normal erythrocytes $^{108}$ and erythrocyte-derived microparticles (MPs) showed phosphatidylserine exposure, ${ }^{106}$ and patients with certain diseases (e.g., SCD) had up to 10 times higher proportion of phosphatidylserine-positive erythrocytes compared with healthy individuals. ${ }^{109}$ Considering that erythrocytes are more abundant (around 20 times higher) and have a larger size than platelets ( $6-10$ vs. $1.5-3 \mu \mathrm{m}$ in diameter, respectively), they may represent a major source of procoagulant phosphatidylserine in a red clot.

WB-TG is dependent on erythrocyte count in reconstituted blood. Using the subsampling technique, Peyrou et $\mathrm{al}^{108}$ and Horne et $\mathrm{al}^{110}$ showed that peak thrombin increased when the erythrocyte count added into PPP increased from 0 to a physiological level (haematocrit $=40 \%$ ), similar to the effect seen when adding platelets into PPP. The ability of erythrocyte to support TG could be related to their membrane phosphatidylserine exposure. ${ }^{108}$ Similar observations were also obtained using fluorogenic methods. ${ }^{87,99,111}$ Moreover, we recently showed that erythrocytes augmented peak thrombin level even in the presence of high platelet count. ${ }^{87}$ Furthermore, both in a group of healthy adults ${ }^{87}$ and cirrhotic patients ${ }^{112}$ we observed a positive correlation between haematocrit and the peak of WB-TG, indicating that erythrocytes have a positive effect on the velocity of WB-TG.

Interestingly, erythrocyte count exhibits a different effect on the ETP than peak height in WB-TG. ${ }^{87}$ In reconstituted blood, ETP was augmented when the haematocrit was increased from 0 to $20 \%$, but it remained largely unchanged when the haematocrit further increased from 20 to $45 \%$. In contrast, the peak of WB-TG was affected in the full range of haematocrit from 0 to $45 \%$. The differential influence of erythrocyte counts on peak and ETP was also observed in the WB-TG profiles of cirrhotic patients. ${ }^{112}$ In cirrhotic patients, erythrocyte and platelet counts are only moderately reduced; however, this reduction in haematocrit decreased the peak thrombin level but not the ETP level of WB-TG. 112 
Studies on the influence of erythrocyte (dys)function on WB-TG in disease settings are scarce. SCD results in elevated plasma TAT and D-dimer levels, and is associated with an increased thrombosis risk. ${ }^{105,113}$ In contrast to in vivo data, in vitro tests in plasma of SCD patients showed that this procoagulant phenotype was not due to plasma factors, as the PPP-TG in SCD patients was comparable or lower than in healthy controls. In WB, it was shown that SCD patients form more TAT complexes in TF-trigged $\mathrm{WB},{ }^{113}$ thus indicating that sickled erythrocytes cause hypercoagulation in SCD patients. A higher percentage of the erythrocytes from SCD were phosphatidylserine positive but, interestingly, the percentage of phosphatidylserine exposure was negatively correlated with WB-TAT formation, suggesting certain cellular factors, other than phosphatidylserine exposure, contribute to TG in SCD. Alternatively, erythrocyte membrane and erythrocyte-derived MPs can trigger coagulation through the intrinsic pathway. ${ }^{114-116}$ Recently, it is shown that an unrecognized protein in erythrocyte MPs directly activated FXII and prekallikrein. ${ }^{117}$ The activation of the contact pathway induces FXI activation; it was also shown that FXIIa and kallikrein can both directly activate FIX. ${ }^{117-119}$

\section{Influence of Erythrocyte-Platelet Interaction on WB- TG}

Platelets and erythrocytes are the most abundant cells in circulating blood and their interactions may be an underestimated player in coagulation. Erythrocytes can directly activate platelets through the release of adenosine triphosphate (ATP) and adenosine diphosphate (ADP). ${ }^{120}$ Additionally, intercellular adhesion molecule 4 (ICAM-4) on erythrocytes was suggested as ligand for $\alpha_{\mathrm{II}} \beta_{3}$ on platelets, ${ }^{121}$ and their interaction was shown to further promote platelet activation as evidenced by increased p-selectin expression. In accordance, the blockage of ICAM- $4-\alpha_{\mathrm{IID}} \beta_{3}$ interaction caused reduced fibrin and thrombus formation in an in vitro perfusion model. ${ }^{106}$ An alternative direct interaction between erythrocytes and platelets is mediated by binding of Fas receptor (FasR) on erythrocytes to Fas ligand (FasL) on activated platelets, which promotes phosphatidylserine exposure on both cells. ${ }^{122}$ Blockage of this interaction leads to reduced thrombus formation underflow, reduced phosphatidylserine exposure on platelets and erythrocytes, as well as reduced WB-TG. FasR- or FasL-knockout mice exhibit delayed initiation of thrombus formation and reduced occlusion after $\mathrm{FeCl}_{3}$ treatment on mesenteric arterioles. ${ }^{122}$ Interfering with the FasL-FasR interaction might be an innovative and promising approach for a completely novel antithrombotic strategy.

\section{Influence of Leukocytes on TG}

Leukocytes are important players in host defence and regulation of inflammatory response. Leukocytes are categorized into neutrophils (constitute $62 \%$ of all leukocytes), eosinophils (2.3\%), basophils ( $0.4 \%)$, lymphocytes (30\%), and monocytes (5.3\%). Monocytes have been known to synthesize and express TF on their cytoplasmic membrane and release TFpositive MPs in response to various cytokines, growth factors and biogenic amines. ${ }^{9}{ }^{123}$ Although lipopolysaccharides (LPS) stimulated monocytes also express TFPI besides TF, it was still able to induce considerable amount of TG, which was only marginally enhanced by anti-TFPI antibodies. ${ }^{124}$ Synthesis of TF in neutrophils is controversial, ${ }^{125-127}$ but neutrophils can release procoagulant matrix metalloproteinases and serine proteases, such as cathepsin $G$ and elastase upon stimulation and directly activate FV, FVIII and FX, as well as down-regulate anticoagulant factors including antithrombin, heparin cofactor II and TFPI. ${ }^{128}$ In addition, stimulated neutrophils release chromatin components, that is, neutrophil extracellular traps (NETs), after exposure to microorganisms, inflammatory cytokines and activated platelets. ${ }^{128,129}$ NETs serve as a scaffold for many procoagulant stimuli, such as platelets, erythrocytes, VWF and TF. ${ }^{130}$ Moreover, several components of NETs have been independently shown to trigger coagulation. For example, histone $\mathrm{H} 4$ directly triggers auto-activation of prothrombin to thrombin, ${ }^{131}$ whereas contact pathway activation can be triggered by purified DNA, albeit different purification methods yield DNA products with drastically different procoagulant activities. $^{132,133}$ Furthermore, activated leukocytes induce platelet activation and aggregation by granule release and ligand-receptor interactions. ${ }^{134}$

\section{Influence of Cancer Cells on TG}

Patients with cancer have a fivefold higher risk of VTE than those without malignancy. ${ }^{135-137}$ The mechanism of cancerassociated hypercoagulability is still unclear and is not always detectable with PPP-TG. ${ }^{138,139}$ Several types of cancer cell lines, including pancreatic, leukaemia and breast origins, express TF, and these cells can induce coagulation in CAT assays. ${ }^{6,7,140}$ Moreover, cancer cell-induced TG is inhibited by anti-TF antibodies, suggesting a role for in vivo TF-positive cancer cells in thrombogenesis, $6,7,140$ although the expression of TF on cancer cells and its effect on TG varies between different cancer types. ${ }^{138}$ Procoagulant MPs have been found both in cultured cancer cell lines ${ }^{141-143}$ and in the circulation of cancer patients, ${ }^{143-145}$ and these vesicles were found to support TG, probably because of TF or phosphatidylserine exposed on their outer membrane. Furthermore, malignant tissues have been reported to produce a cysteine protease that triggers coagulation by directly activating FX independent of FVIIa. ${ }^{146,147}$ Cancer cells also promote coagulation activation indirectly through the activation of other blood cells; tumour-derived factors, such as ADP, thrombin and cytokines can activate platelets and/or leucocytes, resulting in phosphatidylserine-positive platelet surfaces or NETs; both are known to be procoagulant (reviewed in Reddel et $\mathrm{al}^{138}$ and Abdol Razak et $\mathrm{al}^{148}$ ).

Although the influence of leukocytes, cancer cells and MPs on TG has been studied in isolated plasma model systems, their influence in a complex near-physiological environment like WB remains to be assessed. Further studies are needed to advance this field.

\section{WB-TG Assays: Advantages and Limitations}

Compared with plasma tests, WB-TGAs do not need the centrifugation steps for plasma preparation and thus avoid 
the possible pre-analytical variations of plasma preparation and allow faster measurement. By including all circulating cells, WB-TG reaches one step closer to physiology than plasma coagulation tests and may be useful for the assessment of blood cell-related coagulation disorders ( - Table 1 and -Fig. 2). In addition, WB-TG is inhibited by antiplatelet drugs $^{87}$ and anticoagulants (rivaroxaban and dabigatran, unpublished data), suggesting a potential of these assays to serve as a point-of-care (POC) test to monitor anticoagulant and antiplatelet treatments.

The major difference that WB-TGAs have over the currently established POC viscoelastic tests (rotational thromboelastometry [ROTEM] or thromboelastography [TEG]) is that the latter measures the elasticity of a blood clot instead of the amidolytic activity of thrombin. ${ }^{149}$ The viscoelastic tests have shown usefulness for the management of bleeding complications during surgery and in acute trauma care, especially in reducing the amount of blood product transfusion. ${ }^{150}$ However, assessing fibrin clot formation only reflects the procoagulant effect of thrombin, whereas incomplete information is given on the anticoagulant pathways, particularly the anticoagulant effect of thrombin through the protein C pathway. On the contrary, WB-TG covers the entire course of thrombin activation and inactivation, even including the function of the protein $\mathrm{C}$ pathway if thrombomodulin is supplemented, making it more suitable for predicting thrombophilia. ${ }^{87,112}$

WB-TGA is still in its infancy and a long way from clinical application. The lack of standardization on pre-analytical variables and analytical protocols, as well as the absence of standardized reagents and reference sample, greatly hampers the wide evaluation of its clinical application. For example, the use of CTI was shown to improve the reproducibility of plasma-TG when the assay was triggered with low concentration of $\mathrm{TF}^{48,51}$ WB-TG is typically triggered with low amounts of TF $(0.5 \text { or } 1 \mathrm{pM})^{87,99}$ so that coagulation is dependent on physiological PL provided by blood cells and on feedback loops, but whether the use of CTI would also impact the reproducibility of the WB-TGA requires further assessment. The assay trigger should also be optimized for different settings; for instance, a trigger that contains low or even no TF may be necessary to reflect the procoagulant effect of $\mathrm{TF} / \mathrm{phosphatidylserine} \mathrm{on} \mathrm{cancer} \mathrm{cells} \mathrm{or} \mathrm{MPs.} \mathrm{Lastly,} \mathrm{similar}$ to PRP-TGA, the influence of blood flow and endothelium is not represented and it is a technical challenge to develop a standard sample for result normalization.

\section{General Discussion on the Added Value of PRP-TG and WB-TG}

Blood cells are important players in coagulation and can influence TG testing. The complex interplay between platelets and the coagulation system has been underappreciated for many decades. Physiological platelet thrombus formation is augmented by thrombin formation, whereas physiological coagulation is in many stages facilitated by expression of procoagulant surfaces, the expression or activation of specific receptors on platelets and the delivery of FV. As shown earlier, the differentiation of platelet-related coagulation disorders, including platelet secretion/receptor defect, VWD and FXI-related bleeding disorder requires the presence of platelets to ensure a more comprehensive TG profiling. In addition, abnormally high haematocrit, TF-positive cancer cells, inflammation-activated monocytes have all been shown to promote TG by exposing phosphatidylserine and/or TF; therefore, testing WB-TG is a more logical choice than PPP-TG in this context. Furthermore, there are active interactions between blood cells, such as between platelets and erythrocytes or between platelets and leukocytes. The effect of these interactions on TG needs to be assessed in a WB context. Our group recently developed a WB-TGA that shows good correlations with plasma TG tests, with platelet/erythrocyte numbers and with the use of platelet inhibitors ${ }^{87}$ and may serve as a useful tool for studying the involvement of blood cells in coagulation.

There are also limitations with these blood cell-related TGAs. First, there is a lack of standardization. The interlaboratory variation of PPP-TG has been drastically improved by ensuring good thermal control, the use of standardized pre-analytical protocols and reagents, as well as the use of normal pooled plasma to normalize the data in each run. ${ }^{48-52}$ In contrast, the standardization of pre-analytical conditions and analytical variables for PRP-TG and WB-TG are still poor. ${ }^{93}$ Furthermore, due to the limitation that PRP or WB cannot be stored for a long time, there is still no standardized sample for the normalization of the TG parameters in PRP and WB. This may further hamper result comparison between different centres. Second, it is noteworthy that, similar to PPP-TG, some aspects of physiological coagulation are not represented in PRP- or WB-TGAs, including the effect of blood flow and endothelium, although the latter can be partly represented by adding soluble thrombomodulin. Lastly, the differential effect of blood cell counts on the TG parameters, most notably peak and ETP, of PRP-TG and WB-TG calls for caution when interpreting the results of these assays. Further mechanistic and clinical studies are needed to determine which parameter(s), or the integration of parameters into a score, are most useful.

\section{Conflict of Interest}

J.W., J.K., B.d.-L. and M.R. are employed by Synapse Research Institute, which is a part of the Stago group that markets the Calibrated Automated Thrombography and ST-Genesia. T.M.H. is a co-founder of Coagulation Profile BV.

\section{Acknowledgments}

J.W. is supported by an unrestricted scholarship from the China Scholarship Council.

\section{References}

1 MacFarlane RG. An enzyme cascade in the blood clotting mechanism, and its function as a biochemical amplifier. Nature 1964; 202(4931):498-499

2 Davie EW, Ratnoff OD. Waterfall sequence for intrinsic blood clotting. Science 1964;145(3638):1310-1312 
3 van der Meijden PEJ, Munnix ICA, Auger JM, et al. Dual role of collagen in factor XII-dependent thrombus formation. Blood 2009;114(04):881-890

4 Martin DM, Boys CWG, Ruf W. Tissue factor: molecular recognition and cofactor function. FASEB J 1995;9(10):852-859

5 Wilcox JN, Smith KM, Schwartz SM, Gordon D. Localization of tissue factor in the normal vessel wall and in the atherosclerotic plaque. Proc Natl Acad Sci U S A 1989;86(08):2839-2843

6 Rousseau A, Larsen AK, Van Dreden P, Sabbah M, Elalamy I, Gerotziafas GT. Differential contribution of tissue factor and factor XII to thrombin generation triggered by breast and pancreatic cancer cells. Int J Oncol 2017;51(06):1747-1756

7 Marchetti M, Diani E, ten Cate H, Falanga A. Characterization of the thrombin generation potential of leukemic and solid tumor cells by calibrated automated thrombography. Haematologica 2012;97(08):1173-1180

8 Siddiqui FA, Desai H, Amirkhosravi A, Amaya M, Francis JL. The presence and release of tissue factor from human platelets. Platelets 2002;13(04):247-253

9 Celi A, Pellegrini G, Lorenzet R, et al. P-selectin induces the expression of tissue factor on monocytes. Proc Natl Acad Sci U S A 1994;91(19):8767-8771

10 Müller I, Klocke A, Alex M, et al. Intravascular tissue factor initiates coagulation via circulating microvesicles and platelets. FASEB J 2003;17(03):476-478

11 Osterud B, Rapaport SI. Activation of factor IX by the reaction product of tissue factor and factor VII: additional pathway for initiating blood coagulation. Proc Natl Acad Sci U S A 1977;74 (12):5260-5264

12 Josso F, Prou-Wartelle O. Interaction of tissue factor and factor VII at the earliest phase of coagulation. Thromb Diath Haemorrh Suppl 1965;17:35-44

13 O'Donnell JS, O'Sullivan JM, Preston RJS. Advances in understanding the molecular mechanisms that maintain normal haemostasis. Br J Haematol 2019;186(01):24-36

14 Versteeg HH, Heemskerk JW, Levi M, Reitsma PH. New fundamentals in hemostasis. Physiol Rev 2013;93(01):327-358

15 Gailani D, Broze GJ Jr. Factor XI activation in a revised model of blood coagulation. Science 1991;253(5022):909-912

16 Pieters J, Lindhout T, Hemker HC. In situ-generated thrombin is the only enzyme that effectively activates factor VIII and factor V in thromboplastin-activated plasma. Blood 1989;74(03): 1021-1024

17 Fulcher CA, Gardiner JE, Griffin JH, Zimmerman TS. Proteolytic inactivation of human factor VIII procoagulant protein by activated human protein C and its analogy with factor V. Blood 1984; 63(02):486-489

18 Walker FJ. Regulation of activated protein $\mathrm{C}$ by protein $\mathrm{S}$. The role of phospholipid in factor Va inactivation. J Biol Chem 1981;256 (21):11128-11131

19 Comfurius P, Williamson P, Smeets EF, Schlegel RA, Bevers EM, Zwaal RF. Reconstitution of phospholipid scramblase activity from human blood platelets. Biochemistry 1996;35(24): 7631-7634

20 Bevers EM, Rosing J, Zwaal RF. Development of procoagulant binding sites on the platelet surface. Adv Exp Med Biol 1985; 192:359-371

21 Monroe DM, Hoffman M, Roberts HR. Platelets and thrombin generation.Arterioscler ThrombVasc Biol2002;22(09):1381-1389

22 Langdell RD, Wagner RH, Brinkhous KM. Effect of antihemophilic factor on one-stage clotting tests; a presumptive test for hemophilia and a simple one-stage antihemophilic factor assy procedure. J Lab Clin Med 1953;41(04):637-647

23 Quick AJ. On various properties of thromboplastin (aqueous tissue extracts). Am J Physiol Legacy Content 1935;114(02): 282-296

24 Mann KG, Brummel K, Butenas S. What is all that thrombin for? J Thromb Haemost 2003;1(07):1504-1514
25 Tripodi A. Thrombin generation assay and its application in the clinical laboratory. Clin Chem 2016;62(05):699-707

26 Tripodi A, Salerno F, Chantarangkul V, et al. Evidence of normal thrombin generation in cirrhosis despite abnormal conventional coagulation tests. Hepatology 2005;41(03):553-558

27 Hézard N, Bouaziz-Borgi L, Remy MG, Nguyen P. Utility of thrombin-generation assay in the screening of factor $\mathrm{V}$ G1691A (Leiden) and prothrombin G20210A mutations and protein S deficiency. Clin Chem 2006;52(04):665-670

28 MacFarlane RG, Biggs R. A thrombin generation test; the application in haemophilia and thrombocytopenia. J Clin Pathol 1953; $6(01): 3-8$

29 Hemker HC, Wielders S, Kessels H, Béguin S. Continuous registration of thrombin generation in plasma, its use for the determination of the thrombin potential. Thromb Haemost 1993;70 (04):617-624

30 Kelchtermans H, Pelkmans L, Bouwhuis A, et al. Simultaneous measurement of thrombin generation and fibrin formation in whole blood under flow conditions. Thromb Haemost 2016;116 (01):134-145

31 Kremers RMW, Wagenvoord RJ, Hemker HC. The effect of fibrin (ogen) on thrombin generation and decay. Thromb Haemost 2014;112(03):486-494

32 Hemker HC, Giesen P, Al Dieri R, et al. Calibrated automated thrombin generation measurement in clotting plasma. Pathophysiol Haemost Thromb 2003;33(01):4-15

33 Ramjee MK. The use of fluorogenic substrates to monitor thrombin generation for the analysis of plasma and whole blood coagulation. Anal Biochem 2000;277(01):11-18

34 Hemker HC, Giesen P, AlDieri R, et al. The calibrated automated thrombogram (CAT): a universal routine test for hyper- and hypocoagulability. Pathophysiol Haemost Thromb 2002;32 (5-6):249-253

35 Coen Hemker H, Hemker PW, Al Dieri R. The technique of measuring thrombin generation with fluorescent substrates: 4 . The H-transform, a mathematical procedure to obtain thrombin concentrations without external calibration. Thromb Haemost 2009;101(01):171-177

36 Kintigh J, Monagle P, Ignjatovic V. A review of commercially available thrombin generation assays. Res Pract Thromb Haemost 2017;2(01):42-48

37 Al Dieri R, de Laat B, Hemker HC. Thrombin generation: what have we learned? Blood Rev 2012;26(05):197-203

38 Ten Cate H. Thrombin generation in clinical conditions. Thromb Res 2012;129(03):367-370

39 Lutsey PL, Folsom AR, Heckbert SR, Cushman M. Peak thrombin generation and subsequent venous thromboembolism: the Longitudinal Investigation of Thromboembolism Etiology (LITE) study. J Thromb Haemost 2009;7(10):1639-1648

40 Hron G, Kollars M, Binder BR, Eichinger S, Kyrle PA. Identification of patients at low risk for recurrent venous thromboembolism by measuring thrombin generation. JAMA 2006;296 (04):397-402

41 Bosch Y, Al Dieri R, ten Cate H, et al. Preoperative thrombin generation is predictive for the risk of blood loss after cardiac surgery: a research article. J Cardiothorac Surg 2013;8:154

42 Santagostino E, Mancuso ME, Tripodi A, et al. Severe hemophilia with mild bleeding phenotype: molecular characterization and global coagulation profile. J Thromb Haemost 2010;8(04): 737-743

43 Zwaveling S, Bloemen S, de Laat B, Ten Cate H, Ten Cate-Hoek A. Calibrated Automated Thrombinography (CAT), a tool to identify patients at risk of bleeding during anticoagulant therapy: a systematic review. TH Open 2018;2(03):e291-e302

44 Curvers J, Thomassen MC, Rimmer J, et al. Effects of hereditary and acquired risk factors of venous thrombosis on a thrombin generation-based APC resistance test. Thromb Haemost 2002;88 (01):5-11 
45 Rosing J, Tans G, Nicolaes GA, et al. Oral contraceptives and venous thrombosis: different sensitivities to activated protein $\mathrm{C}$ in women using second- and third-generation oral contraceptives. Br J Haematol 1997;97(01):233-238

46 Lisman T, Bakhtiari K, Adelmeijer J, Meijers JC, Porte RJ, Stravitz RT. Intact thrombin generation and decreased fibrinolytic capacity in patients with acute liver injury or acute liver failure. J Thromb Haemost 2012;10(07):1312-1319

47 Dargaud Y, Wolberg AS, Luddington R, et al. Evaluation of a standardized protocol for thrombin generation measurement using the calibrated automated thrombogram: an international multicentre study. Thromb Res 2012;130(06):929-934

48 Dargaud Y, Wolberg AS, Gray E, Negrier C, Hemker HCSubcommittee on Factor VIII, Factor IX, and Rare Coagulation Disorders. Proposal for standardized preanalytical and analytical conditions for measuring thrombin generation in hemophilia: communication from the SSC of the ISTH. J Thromb Haemost 2017;15 (08):1704-1707

49 Dargaud Y, Luddington R, Baglin TP. Elimination of contact factor activation improves measurement of platelet-dependent thrombin generation by calibrated automated thrombography at lowconcentration tissue factor. J Thromb Haemost 2006;4(05): 1160-1161

50 De Smedt E, Hemker HC. Thrombin generation is extremely sensitive to preheating conditions. J Thromb Haemost 2011;9 (01):233-234

51 Subcommittee on Control of Anticoagulation of the SSC of the ISTH. Towards a recommendation for the standardization of the measurement of platelet-dependent thrombin generation. J Thromb Haemost 2011;9(09):1859-1861

52 Dargaud Y, Luddington R, Gray E, et al. Standardisation of thrombin generation test: which reference plasma for TGT? An international multicentre study. Thromb Res 2010;125(04): 353-356

53 van Veen JJ, Gatt A, Makris M. Thrombin generation testing in routine clinical practice: are we there yet? $\mathrm{Br} J$ Haematol 2008; 142(06):889-903

54 Hoffman M, Monroe DM III. A cell-based model of hemostasis. Thromb Haemost 2001;85(06):958-965

55 Reverter JC, Béguin S, Kessels H, Kumar R, Hemker HC, Coller BS. Inhibition of platelet-mediated, tissue factor-induced thrombin generation by the mouse/human chimeric 7E3 antibody. Potential implications for the effect of c7E3 Fab treatment on acute thrombosis and "clinical restenosis". J Clin Invest 1996;98(03): 863-874

56 Sang Y, Roest M, de Laat B, de Groot PG, Huskens D. Interplay between platelets and coagulation. Blood Rev 2021;46:100733

57 Swieringa F, Spronk HMH, Heemskerk JWM, van der Meijden PEJ. Integrating platelet and coagulation activation in fibrin clot formation. Res Pract Thromb Haemost 2018;2(03):450-460

58 Morrissey JH, Choi SH, Smith SA. Polyphosphate: an ancient molecule that links platelets, coagulation, and inflammation. Blood 2012;119(25):5972-5979

59 Verhoef JJF, Barendrecht AD, Nickel KF, et al. Polyphosphate nanoparticles on the platelet surface trigger contact system activation. Blood 2017;129(12):1707-1717

60 Winckers K, Thomassen S, Ten Cate H, Hackeng TM. Platelet full length TFPI- $\alpha$ in healthy volunteers is not affected by sex or hormonal use. PLoS One 2017;12(02):e0168273

61 Preston RJS, Tran S, Johnson JA, et al. Platelet factor 4 impairs the anticoagulant activity of activated protein C. J Biol Chem 2009; 284(09):5869-5875

62 Camire RM, Kalafatis M, Simioni P, Girolami A, Tracy PB. Plateletderived factor $\mathrm{Va} / \mathrm{Va}$ Leiden cofactor activities are sustained on the surface of activated platelets despite the presence of activated protein C. Blood 1998;91(08):2818-2829

63 Brambilla M, Facchinetti L, Canzano P, et al. Human megakaryocytes confer tissue factor to a subset of shed platelets to stimulate thrombin generation. Thromb Haemost 2015;114 (03):579-592

64 Panes O, Matus V, Sáez CG, Quiroga T, Pereira J, Mezzano D. Human platelets synthesize and express functional tissue factor. Blood 2007;109(12):5242-5250

65 Camera M, Frigerio M, Toschi V, et al. Platelet activation induces cell-surface immunoreactive tissue factor expression, which is modulated differently by antiplatelet drugs. Arterioscler Thromb Vasc Biol 2003;23(09):1690-1696

66 Bouchard BA, Gissel MT, Whelihan MF, Mann KG, Butenas S. Platelets do not express the oxidized or reduced forms of tissue factor. Biochim Biophys Acta 2014;1840(03):1188-1193

67 Østerud B, Olsen JO. Human platelets do not express tissue factor. Thromb Res 2013;132(01):112-115

68 Bouchard BA, Krudysz-Amblo J, Butenas S. Platelet tissue factor is not expressed transiently after platelet activation. Blood 2012; 119(18):4338-4339

69 Bouchard BA, Mann KG, Butenas S. No evidence for tissue factor on platelets. Blood 2010;116(05):854-855

70 Brambilla M, Rossetti L, Zara C, et al. Do methodological differences account for the current controversy on tissue factor expression in platelets? Platelets 2018;29(04):406-414

71 Østerud B, Bouchard BA. Detection of tissue factor in platelets: why is it so troublesome? Platelets 2019;30(08):957-961

72 Duckers C, Simioni P, Spiezia L, et al. Residual platelet factor V ensures thrombin generation in patients with severe congenital factor V deficiency and mild bleeding symptoms. Blood 2010; 115(04):879-886

73 Brunet JG, Sharma T, Tasneem S, et al. Thrombin generation abnormalities in Quebec platelet disorder. Int J Lab Hematol 2020;42(06):801-809

74 Vanschoonbeek K, Feijge MAH, Van Kampen RJW, et al. Initiating and potentiating role of platelets in tissue factor-induced thrombin generation in the presence of plasma: subject-dependent variation in thrombogram characteristics. J Thromb Haemost 2004;2(03):476-484

75 Panova-Noeva M, van der Meijden PEJ, Ten Cate H. Clinical applications, pitfalls, and uncertainties of thrombin generation in the presence of platelets. J Clin Med 2019;9(01):E92

76 Shenkman B, Livnat T, Misgav M, Budnik I, Einav Y, Martinowitz $\mathrm{U}$. The in vivo effect of fibrinogen and factor XIII on clot formation and fibrinolysis in Glanzmann's thrombasthenia. Platelets 2012;23(08):604-610

77 Béguin S, Keularts I, Al Dieri R, Bellucci S, Caen J, Hemker HC. Fibrin polymerization is crucial for thrombin generation in platelet-rich plasma in a VWF-GPIb-dependent process, defective in BernardSoulier syndrome. J Thromb Haemost 2004;2(01):170-176

78 Pike GN, Cumming AM, Hay CRM, Bolton-Maggs PH, Burthem J. Sample conditions determine the ability of thrombin generation parameters to identify bleeding phenotype in FXI deficiency. Blood 2015;126(03):397-405

79 Hemker HC. Thrombin generation: biochemical possibilities and clinical reality. Blood 2015;126(03):288-289

80 Kroll MH, Harris TS, Moake JL, Handin RI, Schafer AI. von Willebrand factor binding to platelet GpIb initiates signals for platelet activation. J Clin Invest 1991;88(05):1568-1573

81 Pelkmans L, Miszta A, Al Dieri R, de Laat B, Kelchtermans H. Thrombin generation in the presence of platelets is sensitive to the activation status of von Willebrand factor. Thromb Haemost 2015;113(01):209-211

82 Leebeek FW, Eikenboom JC. Von Willebrand's Disease. N Engl J Med 2016;375(21):2067-2080

83 Rugeri L, Beguin S, Hemker C, et al. Thrombin-generating capacity in patients with von Willebrand's disease. Haematologica 2007;92(12):1639-1646

84 Szanto T, Nummi V, Jouppila A, Brinkman HJM, Lassila R. Platelets compensate for poor thrombin generation in type 3 von Willebrand disease. Platelets 2020;31(01):103-111 
85 Neunert C, Lim W, Crowther M, Cohen A, Solberg L Jr, Crowther MAAmerican Society of Hematology. The American Society of Hematology 2011 evidence-based practice guideline for immune thrombocytopenia. Blood 2011;117(16):4190-4207

86 Tardy-Poncet B, Piot M, Chapelle C, et al. Thrombin generation and heparin-induced thrombocytopenia. J Thromb Haemost 2009;7(09):1474-1481

87 Wan J, Konings J, Yan Q et al. A novel assay for studying the involvement of blood cells in whole blood thrombin generation.J Thromb Haemost 2020;18(06):1291-1301

88 Panova-Noeva M, Schulz A, Spronk HM, et al. Clinical determinants of thrombin generation measured in presence and absence of platelets: results from the Gutenberg Health Study. Thromb Haemost 2018;118(05):873-882

89 Makowski M, Smorag I, Makowska J, et al. Platelet reactivity and mean platelet volume as risk markers of thrombogenesis in atrial fibrillation. Int J Cardiol 2017;235:1-5

90 Giannini EG, Savarino V. Thrombocytopenia in liver disease. Curr Opin Hematol 2008;15(05):473-480

91 Tripodi A, Primignani M, Chantarangkul V, et al. Thrombin generation in patients with cirrhosis: the role of platelets. Hepatology 2006;44(02):440-445

92 Krüger-Genge A, Blocki A, Franke RP, Jung F. Vascular endothelial cell biology: an update. Int J Mol Sci 2019;20(18):E4411

93 de Laat-Kremers RMW, Ninivaggi M, Devreese KMJ, et al. Towards standardization of thrombin generation assays: inventory of thrombin generation methods based on results of an International Society of Thrombosis and Haemostasis Scientific Standardization Committee survey. J Thromb Haemost 2020;18(08): 1893-1899

94 Ljungkvist M, Lövdahl S, Zetterberg E, Berntorp E. Low agreement between fresh and frozen-thawed platelet-rich plasma in the calibrated automated thrombogram assay. Haemophilia 2017;23(03):e214-e218

95 Rand MD, Lock JB, van't Veer C, Gaffney DP, Mann KG. Blood clotting in minimally altered whole blood. Blood 1996;88(09): 3432-3445

96 Thuerlemann C, Haeberli A, Alberio L. Monitoring thrombin generation by electrochemistry: development of an amperometric biosensor screening test for plasma and whole blood. Clin Chem 2009;55(03):505-512

97 Tappenden KA, Gallimore MJ, Evans G, Mackie IJ, Jones DW. Thrombin generation: a comparison of assays using plateletpoor and -rich plasma and whole blood samples from healthy controls and patients with a history of venous thromboembolism. Br J Haematol 2007;139(01):106-112

$98 \mathrm{Al}$ Dieri R, Hemker $\mathrm{CH}$. Thrombin generation in whole blood. $\mathrm{Br} \mathrm{J}$ Haematol 2008;141(06):895

99 Ninivaggi M, Apitz-Castro R, Dargaud Y, de Laat B, Hemker HC, Lindhout T. Whole-blood thrombin generation monitored with a calibrated automated thrombogram-based assay. Clin Chem 2012;58(08):1252-1259

100 Prior SM, Mann KG, Freeman K, Butenas S. Continuous thrombin generation in whole blood: new applications for assessing activators and inhibitors of coagulation. Anal Biochem 2018; 551:19-25

101 Weisel JW, Litvinov RI. Red blood cells: the forgotten player in hemostasis and thrombosis. J Thromb Haemost 2019;17(02): 271-282

102 Byrnes JR, Wolberg AS. Red blood cells in thrombosis. Blood 2017;130(16):1795-1799

103 Sorlie PD, Garcia-Palmieri MR, Costas R Jr, Havlik RJ. Hematocrit and risk of coronary heart disease: the Puerto Rico Health Program. Am Heart J 1981;101(04):456-461

104 Eischer L, Tscholl V, Heinze G, Traby L, Kyrle PA, Eichinger S. Hematocrit and the risk of recurrent venous thrombosis: a prospective cohort study. PLoS One 2012;7(06):e38705
105 Sparkenbaugh E, Pawlinski R. Prothrombotic aspects of sickle cell disease. J Thromb Haemost 2017;15(07):1307-1316

106 Du VX, Huskens D, Maas C, Al Dieri R, de Groot PG, de Laat B. New insights into the role of erythrocytes in thrombus formation. Semin Thromb Hemost 2014;40(01):72-80

107 Helms CC, Marvel M, Zhao W, et al. Mechanisms of hemolysisassociated platelet activation. J Thromb Haemost 2013;11(12): 2148-2154

108 Peyrou V, Lormeau JC, Hérault JP, Gaich C, Pfliegger AM, Herbert JM. Contribution of erythrocytes to thrombin generation in whole blood. Thromb Haemost 1999;81(03):400-406

109 Whelihan MF, Mooberry MJ, Zachary V, et al. The contribution of red blood cells to thrombin generation in sickle cell disease: meizothrombin generation on sickled red blood cells. J Thromb Haemost 2013;11(12):2187-2189

110 Horne MK III, Cullinane AM, Merryman PK, Hoddeson EK. The effect of red blood cells on thrombin generation. $\mathrm{Br} \mathrm{J}$ Haematol 2006;133(04):403-408

111 Walton BL, Lehmann M, Skorczewski T, et al. Elevated hematocrit enhances platelet accumulation following vascular injury. Blood 2017;129(18):2537-2546

112 Wan J, Roberts LN, Hendrix W, et al. Whole blood thrombin generation profiles of patients with cirrhosis explored with a near patient assay. J Thromb Haemost 2020;18(04):834-843

113 Whelihan MF, Lim MY, Mooberry MJ, et al. Thrombin generation and cell-dependent hypercoagulability in sickle cell disease. J Thromb Haemost 2016;14(10):1941-1952

114 Kawakami S, Kaibara M, Kawamoto Y, Yamanaka K. Rheological approach to the analysis of blood coagulation in endothelial cellcoated tubes: activation of the intrinsic reaction on the erythrocyte surface. Biorheology 1995;32(05):521-536

115 Van Der Meijden PE, Van Schilfgaarde M, Van Oerle R, Renné T, ten Cate H, Spronk HM. Platelet- and erythrocyte-derived microparticles trigger thrombin generation via factor XIIa. J Thromb Haemost 2012;10(07):1355-1362

116 Iwata H, Kaibara M. Activation of factor IX by erythrocyte membranes causes intrinsic coagulation. Blood Coagul Fibrinolysis 2002;13(06):489-496

117 Noubouossie DF, Henderson MW, Mooberry M, et al. Red blood cell microvesicles activate the contact system, leading to factor IX activation via 2 independent pathways. Blood 2020;135(10): 755-765

118 Kearney KJ, Butler J, Posada OM, et al. Kallikrein directly interacts with and activates Factor IX, resulting in thrombin generation and fibrin formation independent of factor XI. Proc Natl Acad Sci U S A 2021;118(03):e2014810118

119 Visser M, van Oerle R, Ten Cate H, et al. Plasma kallikrein contributes to coagulation in the absence of factor XI by activating factor IX. Arterioscler Thromb Vasc Biol 2020;40(01):103-111

120 Reimers RC, Sutera SP, Joist JH. Potentiation by red blood cells of shear-induced platelet aggregation: relative importance of chemical and physical mechanisms. Blood 1984;64(06):1200-1206

121 Hermand P, Gane P, Huet M, et al. Red cell ICAM-4 is a novel ligand for platelet-activated $\alpha$ Ilbbeta 3 integrin. J Biol Chem 2003;278(07):4892-4898

122 Klatt C, Krüger I, Zey S, et al. Platelet-RBC interaction mediated by FasL/FasR induces procoagulant activity important for thrombosis. J Clin Invest 2018;128(09):3906-3925

123 Cermak J, Key NS, Bach RR, Balla J, Jacob HS, Vercellotti GM. Creactive protein induces human peripheral blood monocytes to synthesize tissue factor. Blood 1993;82(02):513-520

124 Basavaraj MG, Gruber FX, Sovershaev M, et al. The role of TFPI in regulation of TF-induced thrombogenicity on the surface of human monocytes. Thromb Res 2010;126(05):418-425

125 Maugeri N, Brambilla M, Camera M, et al. Human polymorphonuclear leukocytes produce and express functional tissue factor upon stimulation. J Thromb Haemost 2006;4(06):1323-1330 
126 Darbousset R, Thomas GM, Mezouar S, et al. Tissue factorpositive neutrophils bind to injured endothelial wall and initiate thrombus formation. Blood 2012;120(10):2133-2143

127 Egorina EM, Sovershaev MA, Olsen JO, Østerud B. Granulocytes do not express but acquire monocyte-derived tissue factor in whole blood: evidence for a direct transfer. Blood 2008;111(03): 1208-1216

128 Swystun LL, Liaw PC. The role of leukocytes in thrombosis. Blood 2016;128(06):753-762

129 Brinkmann V, Reichard U, Goosmann C, et al. Neutrophil extracellular traps kill bacteria. Science 2004;303(5663):1532-1535

130 Elaskalani O, Abdol Razak NB, Metharom P. Neutrophil extracellular traps induce aggregation of washed human platelets independently of extracellular DNA and histones. Cell Commun Signal 2018;16(01):24

131 Barranco-Medina S, Pozzi N, Vogt AD, Di Cera E. Histone H4 promotes prothrombin autoactivation. J Biol Chem 2013;288 (50):35749-35757

132 Medeiros SK, Zafar N, Liaw PC, Kim PY. Purification of silica-free DNA and characterization of its role in coagulation. J Thromb Haemost 2019;17(11):1860-1865

133 Smith SA, Baker CJ, Gajsiewicz JM, Morrissey JH. Silica particles contribute to the procoagulant activity of DNA and polyphosphate isolated using commercial kits. Blood 2017;130(01): $88-91$

134 Ghasemzadeh M, Hosseini E. Platelet-leukocyte crosstalk: linking proinflammatory responses to procoagulant state. Thromb Res 2013;131(03):191-197

135 Young A, Chapman O, Connor C, Poole C, Rose P, Kakkar AK. Thrombosis and cancer. Nat Rev Clin Oncol 2012;9(08): 437-449

136 Blom JW, Doggen CJ, Osanto S, Rosendaal FR. Malignancies, prothrombotic mutations, and the risk of venous thrombosis. JAMA 2005;293(06):715-722

137 Heit JA, Silverstein MD, Mohr DN, Petterson TM, O'Fallon WM, Melton LJ III. Risk factors for deep vein thrombosis and pulmonary embolism: a population-based case-control study. Arch Intern Med 2000;160(06):809-815

138 Reddel CJ, Tan CW, Chen VM. Thrombin generation and cancer: contributors and consequences. Cancers (Basel) 2019;11(01): E100
139 Lundbech M, Krag AE, Christensen TD, Hvas AM. Thrombin generation, thrombin-antithrombin complex, and prothrombin fragment $\mathrm{F} 1+2$ as biomarkers for hypercoagulability in cancer patients. Thromb Res 2020;186:80-85

140 Adesanya MA, Maraveyas A, Madden L. Differing mechanisms of thrombin generation in live haematological and solid cancer cells determined by calibrated automated thrombography. Blood Coagul Fibrinolysis 2017;28(08):602-611

141 Hudák R, Debreceni IB, Deák I, et al. Laboratory characterization of leukemic cell procoagulants. Clin Chem Lab Med 2017;55(08): 1215-1223

142 Al Saleh HA, Haas-Neill S, Al-Hashimi A, et al. Thrombotic characteristics of extracellular vesicles derived from prostate cancer cells. Prostate 2018;78(13):953-961

143 Rousseau A, Van Dreden P, Khaterchi A, Larsen AK, Elalamy I, Gerotziafas GT. Procoagulant microparticles derived from cancer cells have determinant role in the hypercoagulable state associated with cancer. Int J Oncol 2017;51(06):1793-1800

144 Gheldof D, Mullier F, Bailly N, et al. Microparticle bearing tissue factor: a link between promyelocytic cells and hypercoagulable state. Thromb Res 2014;133(03):433-439

145 Thomas GM, Panicot-Dubois L, Lacroix R, Dignat-George F, Lombardo D, Dubois C. Cancer cell-derived microparticles bearing P-selectin glycoprotein ligand 1 accelerate thrombus formation in vivo. J Exp Med 2009;206(09):1913-1927

146 Raasi S, Mielicki WP, Gordon SG, Korte W. Properties of proteins in cancer procoagulant preparations that are detected by antitissue factor antibodies. Arch Biochem Biophys 2004;428(02): 131-135

147 Gordon SG, Franks JJ, Lewis B. Cancer procoagulant A: a factor X activating procoagulant from malignant tissue. Thromb Res 1975;6(02):127-137

148 Abdol Razak NB, Jones G, Bhandari M, Berndt MC, Metharom P. Cancer-associated thrombosis: an overview of mechanisms, risk factors, and treatment. Cancers (Basel) 2018;10(10):380

149 Panteleev MA, Hemker HC. Global/integral assays in hemostasis diagnostics: promises, successes, problems and prospects. Thromb J 2015;13(01):5

150 Benes J, Zatloukal J, Kletecka J. Viscoelastic methods of blood clotting assessment: a multidisciplinary review. Front Med (Lausanne) 2015;2:62 